\title{
Learning and Teaching Psychoanalytic Psychotherapy
}

Ann E. Steel, MD

Thomas Jefferson University Hospital

Follow this and additional works at: https://jdc.jefferson.edu/jeffjpsychiatry

Part of the Psychiatry Commons

Let us know how access to this document benefits you

\section{Recommended Citation}

Steel, MD, Ann E. (1986) "Learning and Teaching Psychoanalytic Psychotherapy," Jefferson Journal of Psychiatry. Vol. 4 : Iss. 1 , Article 13.

DOI: https://doi.org/10.29046/JJP.004.1.009

Available at: https://jdc.jefferson.edu/jeffjpsychiatry/vol4/iss $1 / 13$

This Article is brought to you for free and open access by the Jefferson Digital Commons. The Jefferson Digital Commons is a service of Thomas Jefferson University's Center for Teaching and Learning (CTL). The Commons is a showcase for Jefferson books and journals, peer-reviewed scholarly publications, unique historical collections from the University archives, and teaching tools. The Jefferson Digital Commons allows researchers and interested readers anywhere in the world to learn about and keep up to date with Jefferson scholarship. This article has been accepted for inclusion in Jefferson Journal of Psychiatry by an authorized administrator of the Jefferson Digital Commons. For more information, please contact: JeffersonDigitalCommons@jefferson.edu. 


\title{
Book Reviews
}

\section{Learning and Teaching Psychoanalytic Psychotherapy}

\author{
AN INTRODUCTION TO PSYCHOTHERAPY \\ Sidney Tarachow, M.D. \\ New York: International University Press, Inc., \\ 1963. 332 pp., $\$ 32.50$
}

\section{Ann E. Steel, M.D.}

Although written more than 20 years ago, An Introduction to Psychotherapy contains many ideas that are relevant today for both residents in psychiatry and their supervisors.

Dr. Tarachow's book was initially recommended to me by a clinical supervisor in my second year of residency. Later that year I reread most of the book as part of our didactic work for a course entitled "Principles of Analytic Psychotherapy." Now in my third year of residency, I have chosen to review the book, for I have found it to be consistently helpful and informative toward providing good patient care, in exploring the dynamics in certain types of psychopathology, and in examining the process of supervision itself.

With the exception of the first few chapters which comprise the introduction, and the last section devoted to a supervisors' conference, the format of the book is that of discussions between residents and their supervisors. Whether this should be termed "group supervision," discussion, or a seminar, it serves at least two useful purposes: 1) it provides the reader with "an introduction to psychotherapy" that is informal and eminently readable, allowing the resident reader to relate to the residents described in the book, and perhaps to think "I might have said that!' and 2) it provides an example of what supervision might be.

Tarachow introduces his work by noting that he is attempting to teach psychotherapy from a psychoanalytic viewpoint, but not attempting to teach psychoanalysis. At the same time, however, he emphasizes the need for residents to understand the theories and techniques of psychoanalysis even though they may not be practicing it to treat their patients. Tarachow states that "psychoanalysis is by no means the optimal therapy for all psychiatric problems" (p. 4), a

Dr. Steel is a third-year resident at Thomas Jefferson University, Philadelphia, Pennsylvania. 
point which is apt for the types of patients we are likely to see as residents. The author goes on to place particular emphasis on discussion of the nature of the therapeutic relationship and his wish to distinguish the techniques of psychoanalysis and psychotherapy.

Tarachow discusses at length his theory of the therapeutic relationship. In using the term "therapeutic barrier" rather than "therapeutic alliance," Tarachow causes us to examine how we work as therapists in a different way from usual, and to explore what effect the therapeutic relationship may have on ourselves as well as on our patients.

In succeeding chapters Tarachow addresses the practical aspects of his theory, citing vignettes that typically arise in therapy and challenging residents to think about what they would do in these situations. Issues applicable to both inpatient and outpatient work are examined. In "The Theory of Hospital Treatment," inpatient therapy is put into a different light than usual, and seen as "a means of offering a patient an opportunity to act out his psychodynamic patterns under controlled and observed conditions"' (p. 57). This chapter would be useful to any resident working with inpatients, for gaining insight into the dynamics of hospitalization and how to use these to greater therapeutic effect.

Other especially useful chapters include "Gratification and Deprivation" which describes the uses of these two modes in both inpatient and outpatient work, and "Problems Relating to Administration" which details management and political situations commonly encountered in the hospital and their possible solutions. Many chapters are applicable to problems arising in outpatient work: "Structure of the Treatment Relationship" deals with such practical matters as scheduling of appointments, vacations, payment of bills, lateness to appointments, etc. These issues are best handled by exploring them in terms of the individual patient and the manifestations of his psychopathology.

Dr. Tarachow also devotes chapters to the obsessive-compulsive patient, the depressed and suicidal patient, paranoia, homicide, and acting out.

In general, Dr. Tarachow's therapeutic interventions were clearly explained in view of the patient's pathology. There was, however, one particular case in which I found it truly difficult to accept Tarachow's reasoning and action. In this case, cited in the chapter entitled "A History Conference," Dr. Tarachow writes that he insisted that a patient of his have an abortion, for fear that she might commit suicide after the birth of her third child, as her mother had done. Although the author illustrates quite well the case of a daughter potentially compelled to relive her mother's fate, I wondered about some need for discussion of therapeutic alternatives and for discussion of the amount of control that a therapist can realistically take in the lives of his patients.

The book ends with a section directed to supervisors. As a resident I was interested in the dilemma facing supervisors who must decide what their role is in supervision, be it teacher, critic, role model, or possible "object of transference." The importance of the supervisor controlling his inclination to be the resident's therapist is discussed at length. 
I believe that Dr. Tarachow's book is a valuable source of information for residents, particularly those in their second or third year of training, thus having some experience with both inpatient and outpatient work. As a preview to outpatient work it would also be excellent. Finally, as a source of information on interactions with residents and problems that arise during supervision, $A n$ Introduction to Psychotherapy could well be useful to supervisors. 